\title{
Comparison of the body proximate compositions of juvenile bronze gudgeon (Coreius heterodon) and largemouth bronze gudgeon (C. guichenoti) in the upstream region of the Yangtze River
}

\author{
Yiping Luo*, Qingda Huang, Yurong Zhang, Shuting Liu and Wen Wang
}

\begin{abstract}
The body proximate compositions were assessed in juvenile Coreius heterodon and C. guichenoti from the upstream of the Yangtze River. The migratory C. guichenoti has a higher lipid content (FAT) than the residential C. heterodon. FAT of $C$. guichenoti showed an interesting pattern of increase, where FAT increased up rapidly and then leveled off as body mass $(M)$ increased above $6.5 \mathrm{~g}$, suggesting that the lipid concentration reaches an upper limit of deposition. In both species, FAT of the smaller individuals was lower than protein content (PRO), but FAT increased more rapidly than $P R O$ as the fish grew. This indicates that more energy was allocated to protein synthesis than lipid in the smaller fish, with an energy allocation shift from protein synthesis to lipid storage as the fish grew. Strong relationships between both FAT and energy content $(E)$ and water content (WAT) were found in both species, suggesting strong predictive power for future application. However, different models for the two species should be used to predict FAT or E by WAT.
\end{abstract}

Keywords: Body size, Water content, Lipid content, Energy content, Bronze gudgeon

\section{Introduction}

Fish body proximate compositions are important parameters used in fish ecology and physiology, and are related to feeding status (Sogard and Spencer 2004; Blake et al. 2006; Ali et al. 2008), seasons (Jonsson et al. 1997; Berg and Bremset 1998; Robards et al. 1999), habitat (Anthony et al. 2000; Dempson et al. 2004), and body size (Deegan 1986; Shearer et al. 1994; Jonsson and Jonsson 1998, 2003). Changes in the proportions of water, lipid, protein, and ash, result in variation of energy storage in the fish body. This might influence performance related to species fitness, such as the chance of the successful reproduction, survival during seasonal food shortages, and avoidance of predation. In many fish species, the contents of lipid, protein, and energy increase as the fish grows, accompanied by a decrease in water content (Shearer et al. 1994; Jonsson and Jonsson

\footnotetext{
* Correspondence: luoguo@swu.edu.cn

Key Laboratory of Freshwater Fish Reproduction and Development (Southwest University), Ministry of Education, Chongqing 400715, China
}

1998, 2003; Anthony et al. 2000). Data for more species needs to be documented.

Previous studies have found strong relationships between water content or dry mass content and other proximate compositions (Jonsson and Jonsson 1998, 2003; Pangle and Sutton 2005; Hartman and Margraf 2008). Water content is relatively simple to measure, therefore it can be used as an easy indicator to estimate concentrations of lipid, protein, and energy (Van Pelt et al. 1997; Hartman and Margraf 2008). However, prediction models can vary among species (Hartman and Margraf 2008). It is of interest to examine whether a common prediction model is possible for some closely related species.

The bronze gudgeon, Coreius heterodon, and the largemouth bronze gudgeon, Coreius guichenoti, are two related species of wild freshwater fish in China. The two species have many similar biological characteristics, such as body shape, feeding habits and growth parameters. Both are of economic importance, and are the main species found in the mid- and upstream parts of the Yangtze 
River, accounting for $34 \%$ (C. heterodon) and $24 \%$ (C. guichenoti) of total species abundance (Yang et al. 2012). Their population dynamics (Yang et al. 2012), population genetics (Liao et al. 2007; Zhang and Tan 2010), reproductive ecology (Liu et al. 1990) and respiratory physiology (Luo and Wang 2012) have been reported in previous studies. $C$. heterodon resides in a limited river area for its whole life, while C. guichenoti has a special migratory-like behavior. Juvenile $C$. guichenoti live in the area of Chongqing for around 3 to 4 years, then gradually move 600-1000 km up to the Jinsha River (the upper reaches of Yangtze River above Yibin City) and are resident in Jinsha River for their whole lives (Liu et al. 1990; Ding, 1994). Adult fish spawn in the lotic and cooler water from April to July each year and the eggs drift downstream into the Yangtze River (Liu et al. 1990). Long distance movement is an energy expensive process (Hinch and Bratty 2000; Kiessling et al. 2004; Caudill et al. 2007), therefore it could be hypothesized that the fish store sufficient energy before starting to move upstream. However, energy accumulation and growth in the juveniles of this fish are unclear. Therefore, it is of interest to study how the body chemical compositions of juveniles of this species change as their body mass increases. Previous studies have shown that long distance migratory species have greater energy storage and faster deposition of lipids with body growth (Jonsson and Jonsson 1998; Jonsson and Jonsson 2005). Comparison of the body chemical compositions of the migratory $C$. guichenoti and the residential C. heterodon could provide new data for closely related species with different life-history strategies. We hypothesize that $C$. guichenoti has a higher body lipid content of $C$. heterodon.

This study aims to provide energy prediction models for juvenile $C$. guichenoti and $C$. heterodon in the upstream part of the Yangtze River and to determine how the proximate compositions change with body growth in the closely related species with different life-histories.

\section{Materials and methods}

The fish used in this study were collected from the Chongqing area $\left(106^{\circ} 50^{\prime} \mathrm{E}, 29^{\circ} 35^{\prime} \mathrm{N}\right)$ of the upstream part of the Yangtze River in early September 2010. For a map of the sample region, refer to Luo and Wang (2012). Large square nets $(1.5 \mathrm{~cm} \times 1.5 \mathrm{~cm})$ and gill nets $(10 \mathrm{~cm} \times 10 \mathrm{~cm})$ were used to sample fish. Wet mass $(M, \mathrm{~g})$ of the whole fish was measured to $0.01 \mathrm{~g}$ accuracy and body length $(L$, $\mathrm{cm}$ ) was measured to $0.01 \mathrm{~cm}$. The fish were sealed in polyethylene bags and frozen immediately. Fish bodies were dried at $70^{\circ} \mathrm{C}$ for 5 to 15 days until constant mass was obtained to determine the dry mass (g) and water mass (g). The water content (WAT,\%) was calculated from the percentage of water mass to wet body mass. Protein content $(P R O, \%)$ was determined by the Kjeldahl method. Lipid content $(F A T, \%)$ was determined by ether extraction using Soxhlet. Ash content $(A S H, \%)$ was determined by combustion at $550^{\circ} \mathrm{C}$ for 7 hours. Energy content $\left(E, \mathrm{~kJ} \mathrm{~g}^{-1}\right)$ was calculated based on $23.6 \mathrm{~kJ} \mathrm{~g}^{-1}$ of protein and $39.5 \mathrm{~kJ} \mathrm{~g}^{-1}$ of lipid (Brett and Groves 1979). Small individuals of similar size (body length difference within $2 \mathrm{~mm}$ ) were pooled to obtain sufficiently large samples for chemical analysis (15 g wet mass). The mean value of the body length, the body mass, and the chemical composition of each pool was used as one sample. The final sample sizes were 53 for $C$. heterodon and 118 for C. guichenoti.

We used SPSS 11.0 (SPSS Inc., Chicago, IL, USA) for statistical analyses. The relationships between $M$ and chemical composition were described using power curve estimation. The relationships between WAT and other proximate compositions were described using linear regression. General linear model (GLM) followed by least significant difference tests were used to compare the slopes or power exponents and intercepts between the two species, with $M$ as a covariate. Differences were considered significant when the $P$-value was less than 0.05 .

\section{Results}

$L$ of $C$. heterodon ranged from 9.2 to $26.8 \mathrm{~cm}$ with $M$ varying from 11.3 to 293.2 g. $L$ of $C$. guichenoti ranged from 4.6 to $24.6 \mathrm{~cm}$ with $M$ varying from 1.5 to $245.7 \mathrm{~g}$. $M$ and $L$ were significantly correlated in both species (Figure 1).

FAT ranged from $2.02 \%$ to $14.6 \%$ in C. heterodon and from $5.66 \%$ to $20.4 \%$ in C. guichenoti (Figure 2). FAT increased with $M$ in both $C$. heterodon and $C$. guichenoti. The regression of $F A T(\%)$ and $M(\mathrm{~g})$ was $F A T=$ $0.436 M^{0.591}\left(r^{2}=0.651, n=53, P<0.01\right)$ for $C$. heterodon and was $F A T=8.33 M^{0.0753}\left(r^{2}=0.152, n=118, P<0.01\right)$ for

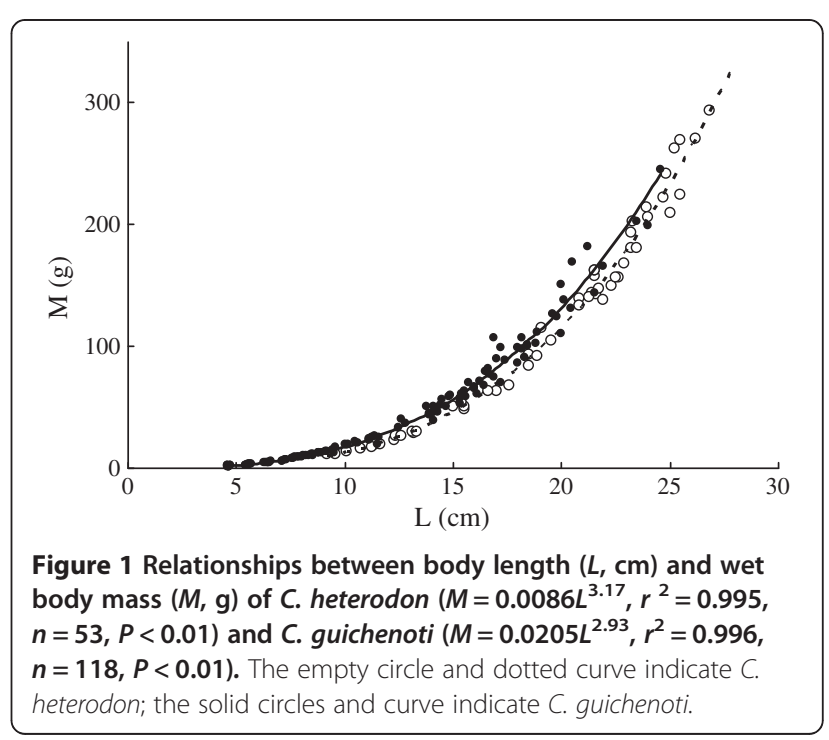




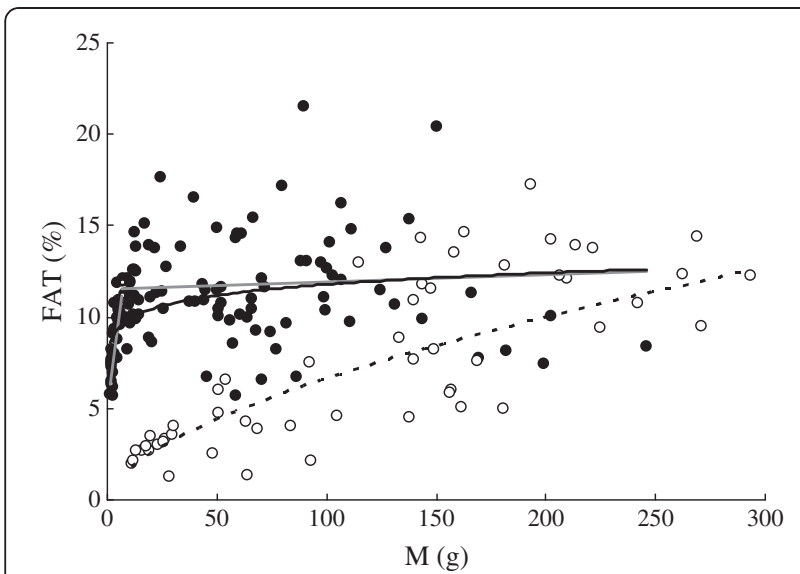

Figure 2 Relationships between wet body mass $(M, \mathrm{~g})$ and body lipid content $(F A T, \%)$ of $C$. heterodon $\left(F A T=0.436 M^{0.591}\right.$, $\left.r^{2}=0.651, n=53, P<0.01\right)$ and $C$. guichenoti $\left(F A T=8.33 M^{0.0753}\right.$, $\left.r^{2}=0.152, n=118, P<0.01\right)$. The empty circle and dotted curve indicate C. heterodon; the solid circles and curve indicate $C$. guichenoti. The grey lines indicate the two-line regressions between FAT and $M$ of $C$. guichenoti. For the fish smaller than transition point $(6.5 \mathrm{~g})$, the regression was FAT $=5.49+0.872 \mathrm{M}\left(r^{2}=0.903, n=24\right.$, $P<0.0001$ ), while for the bigger fish, the regression was $F A T=11.8+$ $0.00290 M\left(r^{2}=0.177, n=94, P>0.05\right)$.

C. guichenoti. FAT of C. guichenoti was significantly higher than that of $C$. heterodon using GLM with $M$ as a covariate $\left(\mathrm{F}_{1}, 170=24.19, P<0.01\right)$. Since $F A T$ of $C$. guichenoti increased and then leveled off as $M$ increased, two-line regressions were also used to describe the relationship between $F A T$ and $M$ for this species. The transition point of these regressions was at $M=6.5 \mathrm{~g}$. For the fish smaller than transition point, the regression was $F A T=5.49+$ $0.872 M\left(r^{2}=0.903, n=24, P<0.0001\right)$, while for the bigger fish, the regression was $F A T=11.8+0.00290 M\left(r^{2}=0.177\right.$, $n=94, P>0.05)$.

PRO ranged from $13.8 \%$ to $19.1 \%$ in $C$. heterodon and from $8.40 \%$ to $17.4 \%$ in C. guichenoti (Figure 3). PRO (\%) of both species were also significantly correlated with $M$ (Figure 3). No significant difference was found in exponent $(b)$ values in the regressions between the two species, using $M$ as a covariate $\left(\mathrm{F}_{1,170}=0.515, \mathrm{P}>0.05\right)$. PRO of $C$. heterodon was significantly higher than that of $C$. guichenoti, using $M$ as a covariate.

ASH ranged from $0.78 \%$ to $5.20 \%$ in C. heterodon and from $1.49 \%$ to $3.15 \%$ in C. guichenoti (Figure 4). ASH (\%) of $C$. heterodon was significantly correlated with $M$ (Figure 4). No significant correlation was found between $A S H$ and $M$ of C. guichenoti. ASH of C. heterodon was significantly higher than that of $C$. guichenoti using GLM with $M$ as a covariate $\left(\mathrm{F}_{1,170}=11.71, P<0.01\right)$.

$E$ ranged from 4.02 to $10.8 \mathrm{~kJ} \mathrm{~g}^{-1}$ in $C$. heterodon and from 5.37 to $11.3 \mathrm{~kJ} \mathrm{~g}^{-1}$ in C. guichenoti (Figure 5). $E\left(\mathrm{~kJ} \mathrm{~g}^{-1}\right)$ of both species were significantly correlated with $M$ (Figure 5). E of C. guichenoti was significantly

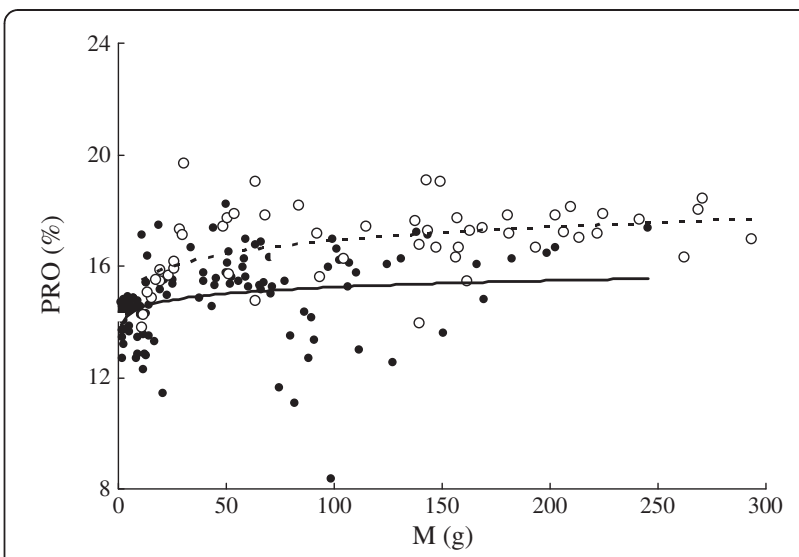

Figure 3 Relationships between wet body mass $(M, g)$ and body protein content $(P R O, \%)$ of $C$. heterodon $\left(P R O=14.0 M^{0.0410}\right.$, $\left.r^{2}=0.234, n=53, P<0.01\right)$ and C. guichenoti $\left(P R O=13.8 M^{0.0221}\right.$, $\left.r^{2}=0.074, n=118, P<0.01\right)$. The empty circle and dotted curve indicate C. heterodon; the solid circles and curve indicate C. guichenoti.

higher than that of $C$. heterodon using GLM with $M$ as a covariate $\left(F_{1}, 170=19.72, P<0.01\right)$. For the fish smaller than the transition point $(19.1 \mathrm{~g})$, the regression was $E=$ $6.12+0.165 M\left(r^{2}=0.705, n=50, P<0.0001\right)$, while for the bigger fish, the regression was $E=8.13+$ $0.00000809 M\left(r^{2}=0.508, n=68, P>0.05\right)$.

WAT (\%) ranged from $63.0 \%$ to $80.7 \%$ in C. heterodon and from $60.6 \%$ to $78.0 \%$ in C. guichenoti and both decreased with $M(\mathrm{~g})$ (Figure 6). The $b$-value of the regression was significantly lower $\left(\mathrm{F}_{1}, \mathrm{1}_{170}=8.04, P<0.01\right)$, while the intercept was significantly higher in $C$. heterodon $\left(\mathrm{F}_{1}, 170=26.08, P<0.01\right)$ than those of $C$. guichenoti, using GLM with $M$ as a covariate.

WAT was negatively linearly correlated with FAT or $E$ in both species (Figure $7 \mathrm{a}, \mathrm{b}$ ). A significant difference was found in the regression slopes between the two

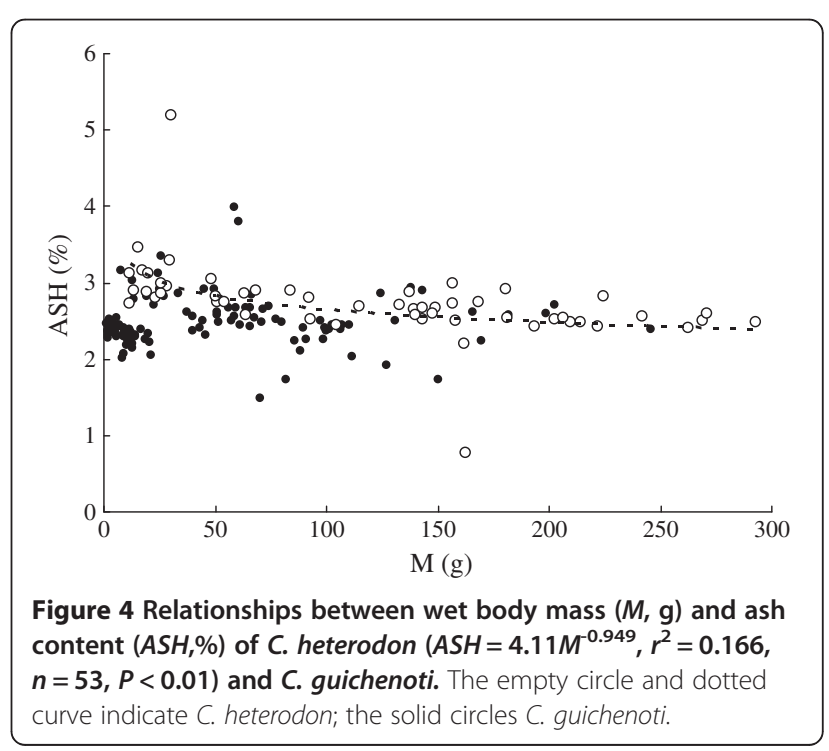




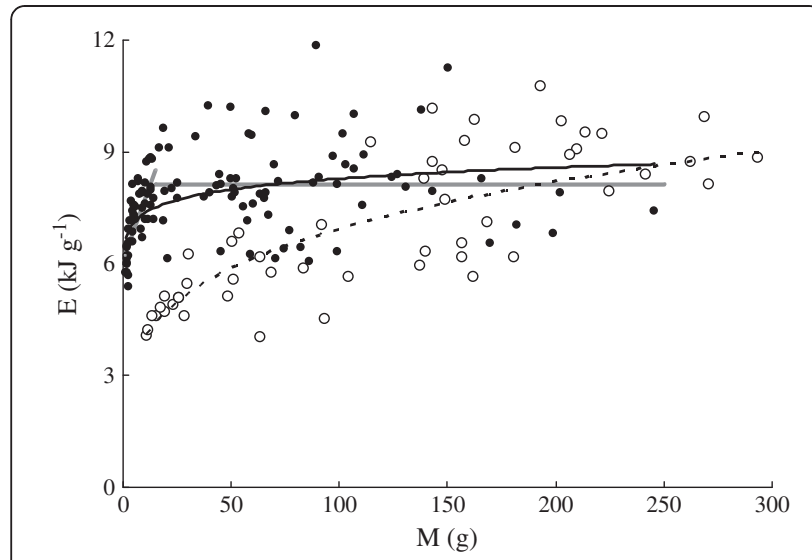

Figure 5 Relationships between wet body mass $(M, \mathrm{~g})$ and energy content $\left(E \mathrm{~kJ} \mathrm{~g}^{-1}\right)$ of $C$. heterodon $\left(E=2.27 \mathrm{M}^{0.242}\right.$, $\left.r^{2}=0.667, n=53, P<0.01\right)$ and $C$. guichenoti $\left(E=6.55 M^{0.0511}\right.$, $\left.r^{2}=0.219, n=118, P<0.01\right)$. The empty circle and dotted curve indicate C. heterodon; the solid circles and curve indicate C. guichenoti. The grey lines indicate the two-line regressions between $E$ and $M$ of $C$. guichenoti. For the fish smaller than transition point $(19.1 \mathrm{~g})$, the regression was $E=6.12+0.165 \mathrm{M}\left(r^{2}=0.705, n=50, P<0.0001\right)$, while for the bigger fish, the regression was $E=8.13+0.00000809 \mathrm{M}$ $\left(r^{2}=0.508, n=68, P>0.05\right)$.

species (ANCOVA, $\mathrm{F}_{1}, 170=26.94$ for FAT, $P<0.01$; $F_{1,170}=31.49$ for $\left.E, P<0.01\right)$. Significant correlations were also found between WAT and both PRO and ASH but with smaller $r^{2}$ values (Figure $7 \mathrm{c}, \mathrm{d}$ ).

\section{Discussion}

The exponent values of the length-mass relationships of both C. heterodon (3.17) and C. guichenoti (2.93) estimated in this study (Figure 1) were within the general range found for fishes (2.5 to 3.5) in previous studies (Carlander 1969). The exponent value of C. heterodon

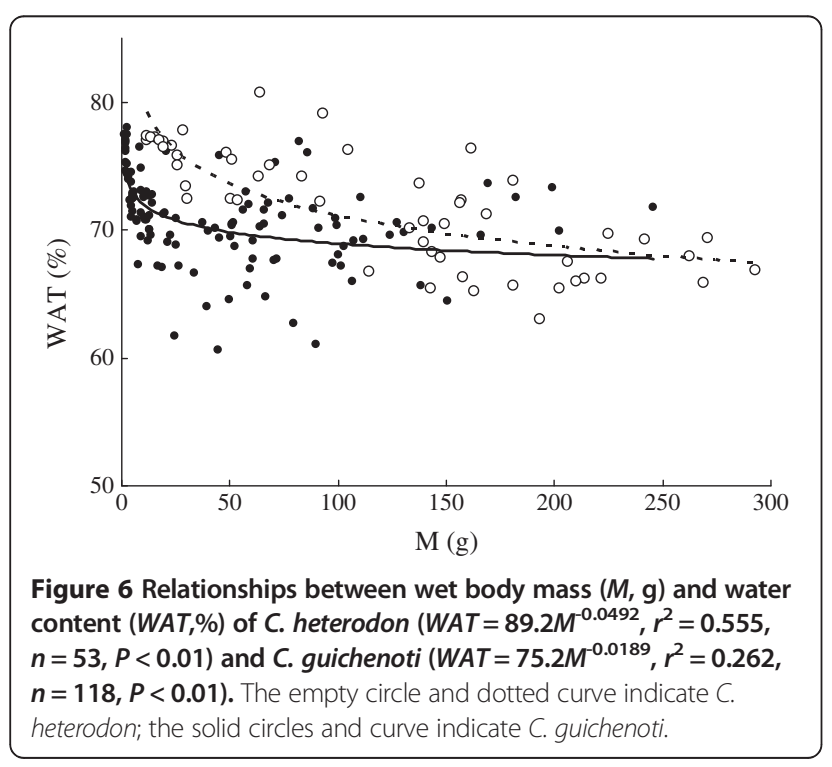

indicates a positively allometric growth, while the exponent value of $C$. guichenoti (2.93) indicates an approximately isometric growth. The faster increase of weight than length of $C$. heterodon in this study indicates that bone mass tends to increase at a slower rate than does muscle mass, as stated by Shearer (1994). Correspondingly, in this study $A S H$ decreased with $M$ of $C$. heterodon (Figure 4), which could reflect a slower increase in bone mass. The isometric growth of $C$. guichenoti is also consistent with its unchanged $A S H$ with $M$.

FAT of C. guichenoti was relatively higher than that of C. heterodon (Figure 2). Childs and King (1993) classified fishes into low fat fish (FAT within 0.6-3.0\%), intermediate fat fish (FAT within $3.5 \%$ to $7.0 \%$ ) and high fat fish (FAT within $8.5 \%$ to $15.3 \%$ ). C. guichenoti (FAT ranges $5.66 \%$ to $20.4 \%$ ) could be incorporated into the intermediate or high fat categories and some individuals of larger size even having $F A T$ above the range of high fat categories. C. heterodon (FAT ranges $2.02 \%$ to $14.6 \%$ ) could be incorporated into intermediate or low fat categories. It has been found that the long distance migratory species deposit larger amounts of body lipid (Jonsson and Jonsson 2005), which could be the reason for the higher $F A T$ of the migratory C. guichenoti than that of the residential $C$. heterodon.

FAT, PRO, and $E$ of many fish species increase as the body size increases (Berg and Bremset 1998; Jonsson and Jonsson 1998, 2003; Sogard and Spencer 2004). Similar results were also found in the both species in this study (Figures 2, 3 and 5). However, FAT of $C$. guichenoti showed an interesting pattern of increase, where $F A T$ increased rapidly and then leveled off as $M$ increased above 6.5 g. E of C. guichenoti also increased in a similar two-line pattern but with a relative larger transition body mass of $19.1 \mathrm{~g}$. This was partly contributed to by the persistent increase in PRO. This suggests that the lipid concentration of C. guichenoti reaches an upper limit. Thus, the energy storage of larger fish needed for migration may depend mainly on increase of body size rather than body energy density.

$P R O$ of the smaller individuals of both species was higher than $F A T$, indicating that more intake energy was allocated to synthesis of protein than lipid (Figures 2 and 3). Similar results were also reported in Atlantic salmon (Salmo salar), brown trout (S. trutta), and sablefish (Anoplopoma fimbria) (Berg and Bremset 1998; Jonsson and Jonsson 1998; Sogard and Spencer 2004). The strategy of protein build-up of fish fry might enhance their competition capacity and reduce predation risk (Calow 1985). Furthermore, $F A T$ of both species increases faster than $P R O$ as the fishes grow. This suggests that the importance of lipid increases and there is a shift in energy allocation from protein synthesis to lipid storage. Similar 


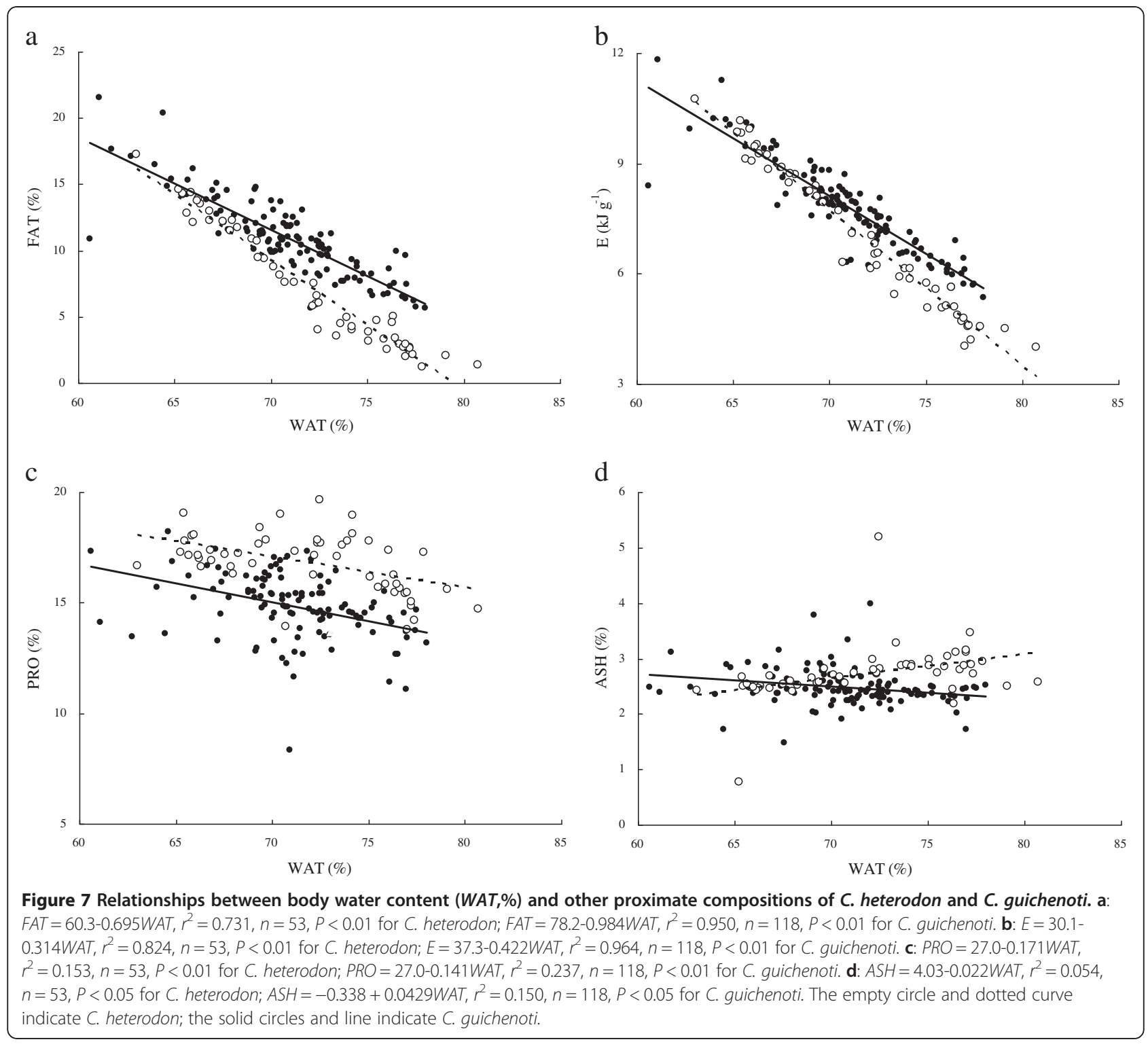

results were also found in gulf menhaden (Brevoortia patronus) (Deegan 1986) and many other species (Shearer et al. 1994; Anthony et al. 2000).

Previous studies (Hartman and Brandt, 1995; Jonsson and Jonsson 1998; Pangle and Sutton 2005; Hartman and Margraf 2008) have suggested using dry mass content or water content to predict the proximate composition of fishes. The present study also found significant relationships between WAT and FAT, PRO, ASH, or E in both fish species (Figure 7 a, b, c, d). The models for FAT or $E$ of both species yielded high $r^{2}$ values (range: 0.731 to 0.964$)$ suggesting strong predictive power for future application. However, variation of $P R O$ and $A S H$ could be explained less well by WAT $\left(r^{2}\right.$ values range: 0.054 to 0.237 ). The lower predictive power of models for PRO and $A S H$ may be related to narrow ranges of protein and ash contents in both $C$. heterodon and $C$. guichenoti. Fishes may exchange body water and fat when energy budgets change (Hartman and Margraf 2008). Previous studies suggest that the equal amounts of decrease in body water are associated with the accumulation of around three times as much lipid as protein (Schmidt-Nielsen 1975; Jobling 1994). The present results showed that the slopes of WAT-FAT model were 4.1 times higher in C. heterodon and 2.3 times higher in C. guichenoti, compared with the slopes of WAT-PRO model, suggesting a rapider accumulation of lipid. Similar rapider accumulation of lipid was also found in brown trout (Jonsson and Jonsson 1998) and Atlantic salmon (Jonsson and Jonsson 2003).

Our results also showed significant differences between the two species of the slopes in both WAT-FAT 
and WAT-E models (Figure $7 \mathrm{a}, \mathrm{b}$ ). Equal changes in body water would induce 1.4 times the change in FAT and 1.3 times the change in $E$ for $C$. guichenoti compared with $C$. heterodon. This suggests that, even between closely related species, FAT and $E$ cannot be predicted by WAT using general models. Further work is needed to determine whether the stronger replacement between water and lipid in C. guichenoti is related to its migratory characteristics.

For future work, different models for the two species should be used to predict FAT or E by WAT. The migratory C. guichenoti has a higher FAT than that of the residential $C$. heterodon. With dam constructions in the upstream region of the Yangtze River, C. guichenoti is undergoing loss of its migratory pathway and even its migratory behavior. Its energetic response to the intense changes of habitat remains unclear and would be an interesting area of future research.

\section{Competing interests}

The authors declare that they have no competing interests.

\section{Authors' contributions}

YL planned the research strategy of the study and was involved in the interpretation of the data. YL also performed the field sample, the subsequent biochemical analysis and the preparation of the manuscript. QH contributed to the sample treatment and analysis of fish dry mass content. YZ contributed to the analysis of protein content. SL contributed to the analysis of protein content and ash content. WW contributed to the analysis of lipid content. All authors read and approved the final manuscript.

\section{Acknowledgments}

This study was supported by the National Natural Science Foundation of China (31000958) and the Special Fund of Chongqing Key Laboratory (CSTC).

Received: 29 December 2012 Accepted: 22 February 2013

\section{Published: 28 February 2013}

\section{References}

Ali A, Al-Ogaily SM, Al-Asgah NA, Goddard JS, Ahmed SI (2008) Effect of feeding different protein to energy $(\mathrm{P} / \mathrm{E})$ ratios on the growth performance and body composition of Oreochromis niloticus fingerlings. J Appl Ichthyol 24:31-37

Anthony JA, Roby DD, Turco KR (2000) Lipid content and energy density of forage fishes from the northern gulf of Alaska. J Exp Mar Biol Ecol 248:53-78

Berg OK, Bremset G (1998) Seasonal changes in the body composition of young riverine Atlantic salmon and brown trout. J Fish Biol 52:1272-1288

Blake RW, Inglis SD, Chan KHS (2006) Growth, carcass composition and plasma growth hormone levels in cyclically fed rainbow trout. J Fish Biol 69:807-817

Brett JR, Groves TDD (1979) Physiological energetics in "Fish Physiology". Academic, New York, pp 279-352, 8

Calow P (1985) Adaptive aspects of energy allocation. In: Tytler P, Calow P (eds) Fish Energetics: New Perspectives. John Hopkins University Press, Baltimore, pp 13-31

Carlander KD (1969) Handbook of freshwater fishery biology. The lowa State University Press, I. Ames, p 752

Caudill CC, Daigle WR, Keefer ML, Boggs $C T$, Jepson MA, Burke BJ, Zabel RW, Bjornn TC, Peery CA (2007) Slow dam passage in adult Columbia River salmonids associated with unsuccessful migration: delayed negative effects of passage obstacles or condition-dependent mortality? Can J Fish Aquat Sci 64:979-995

Childs MT, King IB (1993) Dietary importance of fish and shell fish. In: Macrae R, Robinson RK, Sadler M (eds) Encyclopedia of food science, Food Technology and Nutrition. Academic, III. London, pp 1877-1881

Deegan LA (1986) Changes in body composition and morphology of youngof-the-year gulf menhaden, Brevoortia patronus Goode, in Fourleague Bay, Louisiana. J Fish Biol 29:403-415
Dempson JB, Schwarz CJ, Shears M (2004) Comparative proximate body composition of Atlantic salmon with emphasis on parr from fluvial and lacustrine habitats. J Fish Biol 64:1257-1271

Ding RH (1994) The fishes of Sichuan. Sichuan Publishing House of Science and Technology, Chengdu, pp 238-240

Hartman KJ, Brandt SB (1995) Estimating energy density of fish. T Am Fish Soc 124:347-355

Hartman KJ, Margraf FJ (2008) Common relationships among proximate composition components in fishes. J Fish Biol 73:2352-2360

Hinch SG, Bratty JM (2000) Effects of swim speed and activity pattern on success of adult sockeye salmon migration through an area of difficult passage. T Am Fish Soc 129:604-612

Jobling M (1994) Fish Bioenergetics. Chapman and Hall, London

Jonsson B, Jonsson N (2005) Lipid energy reserves influence life-history decision of Atlantic salmon (Salmo salar) and brown trout (S. trutta) in fresh water. Ecol Freshw Fish 14:296-301

Jonsson N, Jonsson B, Hansen L (1997) Changes in proximate composition and estimates of energetic costs during upstream migration and spawning in Atlantic salmon Salmo salar. J Anim Ecol 66:425-436

Jonsson N, Jonsson B (1998) Body composition and energy allocation in lifehistory stages of brown trout. J Fish Biol 53:1306-1316

Jonsson N, Jonsson B (2003) Energy allocation among developmental stages, age groups, and types of Atlantic salmon (Salmo salar) spawners. Can J Fish Aquat Sci 60:506-516

Kiessling A, Lindahl-Kiessling K, Kiessling K (2004) Energy utilization and metabolism in spawning migrating early start sockeye salmon (Oncorhynchus nerka): the migratory paradox. Can J Fish Aquat Sci 61:452-465

Liao X, Yu X, Chang J, Tong J (2007) Polymorphic microsatellites in largemouth bronze gudgeon (Coreius guichenoti) developed from repeat-enriched libraries and cross-species amplifications. Mol Ecol Notes 7:1 104-1107

Liu L, Wu G, Wang Z (1990) Reproduction ecology of Coreius heterodon (Bleeker) and Coreius guichenoti (Sauvage et Dabry) in the mainstream of the Changjiang River after the construction of Gezhouba Dam. Acta Hydrobiol $\operatorname{Sin} 14: 205-215$

Luo YP, Wang QQ (2012) Effect of body size and temperature on the resting metabolic rate of juvenile largemouth bronze gudgeon. J Fish Biol 80:842-851

Pangle KL, Sutton TM (2005) Temporal changes in the relationship between condition indices and proximate composition of juvenile Coregonus artedi. J Fish Biol 66:1060-1072

Robards MD, Anthony JA, Rose GA, Piatt JF (1999) Changes in proximate composition and somatic energy content for Pacific sand lance (Ammodytes hexapterus) from Kachemak Bay, Alaska relative to maturity and season. J Exp Mar Biol Ecol 242:245-258

Schmidt-Nielsen K (1975) Animal Physiology: Adaptation and Environment. Cambridge University Press, London

Shearer KD (1994) Factors affecting the proximate composition of cultured fishes with emphasis on salmonids. Aquaculture 119:63-88

Shearer KD, Åsgård T, Andorsdöttir G, Aas GH (1994) Whole body elemental and proximate composition of Atlantic salmon (Salmo salar) during the life cycle. J Fish Biol 44:785-797

Sogard SM, Spencer ML (2004) Energy allocation in juvenile sablefish: effects of temperature, ration and body size. J Fish Biol 64:726-738

Van Pelt TI, Piatt JF, Lurtce BK, Roby DD (1997) Proximate composition and energy density of some north Pacific forage fishes. Comp Biochem Physiol A 118:1393-1398

Yang S, Gao X, Li M, Ma B, Liu H (2012) Interannual variations of the fish assemblage in the transitional zone of the Three Gorges Reservoir: persistence and stability. Environ Biol Fish 93:295-304

Zhang F, Tan D (2010) Genetic diversity in population of largemouth bronze gudgeon (Coreius guichenoti Sauvage et Dabry) from Yangtze River determined by microsatellite DNA analysis. Gen Genet Syst 85:351-357

doi:10.1186/2193-1801-2-75

Cite this article as: Luo et al:: Comparison of the body proximate compositions of juvenile bronze gudgeon (Coreius heterodon) and largemouth bronze gudgeon (C. guichenoti) in the upstream region of the Yangtze River. SpringerPlus 2013 2:75. 